\title{
水耕における溶存 $\mathbf{O}_{2}$ 濃度制御下のキュウリ植物の吸水
}

\author{
吉田敏・北野雅 治・江口弘美 \\ 九州大学生物環境調節研究センター
Water Uptake in Cucumber Plants (Cucumis sativus L.) under Control of Dissolved $\mathrm{O}_{2}$ Concentration in Hydroponics \\ Satoshi YoshidA, Masaharu KITANo and Hiromi EGUCHI \\ Biotron Institute, Kyushu University, 12, Fukuoka 812-81, Japan

\begin{abstract}
For analyzing the effect of dissolved $\mathrm{O}_{2}$ concentration on root water uptake in hydroponics, the stem base water flux in cucumber plants (Cucumis sativus L.) was measured by heat flux control method (HFC) in "a" newly developed system for controlling dissolved $\mathrm{O}_{2}$ concentration. At an air temperature of $25^{\circ} \mathrm{C}$, a relative humidity of 70\%, a PPFD of $300 \mu \mathrm{mol} \mathrm{m}^{-2} \mathrm{~s}^{-1}$ (a photoperiod of $12 \mathrm{~h}$ ) and a root temperature of $25^{\circ} \mathrm{C}$, dissolved $\mathrm{O}_{2}$ concentration was controlled at set values of $0.01,0.10$ and $0.20 \mathrm{~mm}$ with an accuracy of $\pm 0.005 \mathrm{~mm}$. At each dissolved $\mathrm{O}_{2}$ concentration, the water uptake rate drastically increased by lighting the plant, and water uptake reduced in proportion to decrease in dissolved $\mathrm{O}_{2}$ concentration : Water uptakes per day at $0.20,0.10$ and $0.01 \mathrm{~mm}$ were 235,186 and $164 \mathrm{~g}$, respectively. This fact suggests that root water uptake in hydroponics is depressed at lower dissolved $\mathrm{O}_{2}$ concentrations by change in membrane permeability of root cells through respiration-dependent processes.
\end{abstract}

(Received September 13, 1995)

1995 年 9 月 13 日受付

緒

言

水耕において, 培養液の溶存 $\mathrm{O}_{2}$ 濃度が低い条件下 では植物の生育や収量が減少することが知られている (位田, 1977). Chun and Takakura（1994）は, レタ ス植物の水耕において溶存 $\mathrm{O}_{2}$ 濃度の低下にともなっ て根の呼吸速度が減少することを明らかにしている。 さらに, 低溶存 $\mathrm{O}_{2}$ 濃度条件下では根の細胞分裂が遅 れ, 伸長が抑制される一方, 分岐根が増加する等, 根 の生育に対する溶存 $\mathrm{O}_{2}$ 濃度の作用が認められている (Atwell et al., 1985; Giménez-Abian et al., 1987 ; Wiedenroth, 1993).このような溶存 $\mathrm{O}_{2}$ 濃度は吸水に も作用していると考えられる.そこで本研究では, キュ ウリ植物において根の吸水に対する溶存 $\mathrm{O}_{2}$ 濃度の影 響を調べることを目的として，溶存 $\mathrm{O}_{2}$ 濃度制御下に おいて根の吸水速度の動態をオンライン計測によって
調べた。

\section{材料および方法}

\section{植物 材 料}

植物材料としては，キュウリ（Cucumis sativus L.) 品種「長日落合 2 号」を用いた。育苗時の水耕におい ては, 培責液を Table 1 に示す組成とし, 環境条件を 気温 $23^{\circ} \mathrm{C}$, 湿度 $70 \% \mathrm{RH}$, 光強度 PPFD $350 \mu \mathrm{mol} \mathrm{m}^{-2}$ $\mathrm{s}^{-1}$ (メタルハライドランプ DR400/T (L), 東芝ライ テック)，12 時間日長 $(8: 00 \sim 20: 00)$ および飽和溶存 $\mathrm{O}_{2}$ 濃度とした. 実験には, 第 3 本葉が展開した植物 (播 種後 21 日, 葉面積 $474 \pm 23 \mathrm{~cm}^{2}$ ) を用いた。育苗時と 同じ組成の培養液において溶存 $\mathrm{O}_{2}$ 濃度条件を 0.01 $\mathrm{mM}, 0.10 \mathrm{mM}$ および $0.20 \mathrm{mM}$ に設定し，それぞれ 3 個 体を供試した。植物体を溶存 $\mathrm{O}_{2}$ 濃度制御装置に植栽 した後, 2 日目に測定を行った.このとき, 培養液中の 細菌の増殖を抑制するためにストレプトマイシン 
Table 1 Concentrations of elements in nutrient solution.

\begin{tabular}{lrl}
\hline Element & $\begin{array}{c}\text { Concentration } \\
(\mathrm{mM})\end{array}$ & \multicolumn{1}{c}{ Solute } \\
\hline$\left[\mathrm{NO}_{3}{ }^{-}\right]$ & 30.84 & $\mathrm{KNO}_{3}, \mathrm{Ca}\left(\mathrm{NO}_{3}\right)_{2} 4 \mathrm{H}_{2} \mathrm{O}$ \\
{$\left[\mathrm{NH}_{4}{ }^{+}\right]$} & 3.21 & $\mathrm{NH}_{4} \mathrm{H}_{2} \mathrm{PO}_{4}$ \\
{$\left[\mathrm{PO}_{4}{ }^{3-}\right]$} & 3.38 & $\mathrm{NH}_{4} \mathrm{H}_{2} \mathrm{PO}_{4}$ \\
{$\left[\mathrm{~K}^{+}\right]$} & 15.25 & $\mathrm{KNO}_{3}, \mathrm{KOH}^{2}$ \\
{$\left[\mathrm{Ca}^{2+}\right]$} & 8.20 & $\mathrm{Ca}\left(\mathrm{NO}_{3}\right)_{2} 4 \mathrm{H}_{2} \mathrm{O}$ \\
{$\left[\mathrm{Mg}^{2+}\right]$} & 3.72 & $\mathrm{MgSO}_{4} 7 \mathrm{H}_{2} \mathrm{O}$ \\
{$\left[\mathrm{BO}_{3}{ }^{3-}\right]$} & 0.09 & $\mathrm{H}_{3} \mathrm{BO}_{3}$ \\
{$\left[\mathrm{Fe}^{2+}\right]$} & 0.10 & $\mathrm{C}_{10} \mathrm{H}_{12} \mathrm{~N}_{2} \mathrm{O}_{8} \mathrm{FeNa} \mathrm{H}_{2} \mathrm{O}$ \\
{$\left[\mathrm{Mn}^{2+}\right]$} & 0.04 & $\mathrm{MnSO}_{4} 4 \mathrm{H}_{2} \mathrm{O}$ \\
\hline
\end{tabular}

(0.25 mM) を添加した。

\section{溶存 $\mathbf{O}_{2}$ 濼度制御装置}

Fig. 1 に, 新たに開発した溶存 $\mathrm{O}_{2}$ 濃度制御装置を示 す.ステンレスポット（容量 $4 \mathrm{~L}$ ）に植物体を植栽し, ゴム栓およびワセリンを用いて培養液と外気とを遮断 した. 培養液の溶存 $\mathrm{O}_{2}$ 濃度の制御にあたり, 根の呼吸 による溶存 $\mathrm{O}_{2}$ の吸収分を補うために, 連続通気に よって $\mathrm{O}_{2}$ で飽和した培養液を新たに供給した。すな わち, フィードバックセンサとしてポーラログラフ方 式溶存 $\mathrm{O}_{2}$ センサ (DO-4, 東京理化器械) を用いてポッ
ト内の溶存 $\mathrm{O}_{2}$ 濃度を計測し, コントローラ（FM-11, 東京理化器械）により送液ポンプ（peristaltic pump； 流量 $100 \mathrm{~mL} \mathrm{~min}^{-1}$ ) を ON-OFF 操作し， $\mathrm{O}_{2}$ で飽和さ せた培責液をポットに供給した。ポットから排出され た培養液はガラス容器 (容量 $500 \mathrm{~mL}$ ) をとおしてオー バーフローさせ, 培養液タンクに循環させて再度通気 を行った。送液ポンプ停止時には，根の吸水に相当す る少量の培養液をガラス容器から逆流させることによ り,ポットへの外気の混入を防いだ。本研究では, 溶 存 $\mathrm{O}_{2}$ 濃度の設定値を $0.01 \mathrm{mM}, 0.10 \mathrm{mM}$ および 0.20 $\mathrm{mM}$ とした。 また, 溶存 $\mathrm{CO}_{2}$ センサ (CGP-1, 東亜電 波工業) および $\mathrm{pH}$ センサ（HM-7E，東亜電波工業） を用いて溶存 $\mathrm{CO}_{2}$ 濃度および $\mathrm{pH}$ を計測した。各セン サからの出力信号をオンラインでコンピュータに入力 した。ポット内の根部環境条件を均一にするために， スターラを用いて培養液を常に摫汼した。このポット を水温 $25^{\circ} \mathrm{C}$ に制御したウォータバスに設置してポッ ト内の培養液温度 (根温)を $25^{\circ} \mathrm{C}$ に維持した。ささら, この装置を人工照明グロースキャビネット内に設置 し, 地上部環境を気温 $25^{\circ} \mathrm{C}$, 湿度 $70 \% \mathrm{RH}$ に制御した。 光条件としては，白色蛍光灯 $(F L R 110 \mathrm{EH} \cdot \mathrm{W} / \mathrm{A}$, 東芝 ライテック；PPFD $\left.280 \mu \mathrm{mol} \mathrm{m}{ }^{-2} \mathrm{~s}^{-1}\right)$ および白熱灯 (BRF100V, 東芝ライテック；PPFD $20 \mu \mathrm{mol} \mathrm{m}^{-2} \mathrm{~s}^{-1}$ )

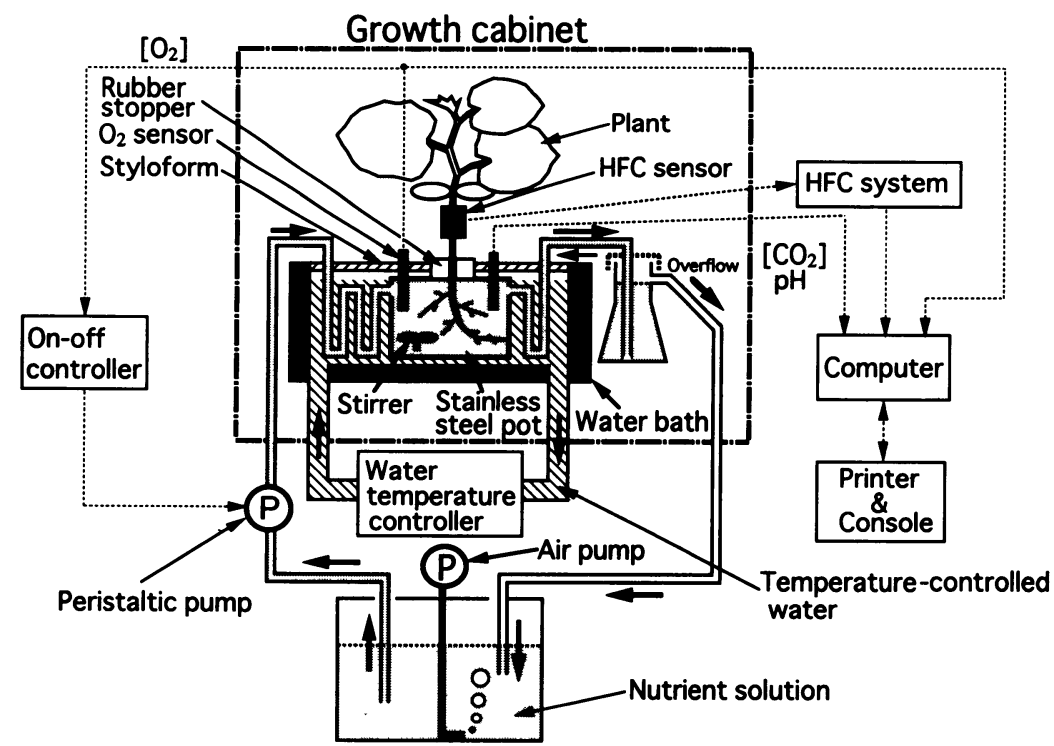

Fig. 1 Schematic diagram of a control system of dissolved $\mathrm{O}_{2}$ concentration in hydroponics.

$\left[\mathrm{O}_{2}\right]$, dissolved $\mathrm{O}_{2}$ concentration in stainless steel pot (root environment); $\left[\mathrm{CO}_{2}\right]$, dissolved $\mathrm{CO}_{2}$ concentration in stainless steel pot; HFC, heat flux control method for measurement of water uptake rate in roots of an intact cucumber plant. 
を用いて光強度を PPFD $300 \mu \mathrm{mol} \mathrm{m}^{-2} \mathrm{~s}^{-1}, 12$ 時間日 長 $(8: 00 〜 20: 00)$ とした.

\section{HFC 法による根の吸水速度の計測}

前述のように, 培養液の循環によって溶存 $\mathrm{O}_{2}$ 濃度 の制御を行う場合には, 重量法あるいはポトメー夕法 を用いて根の吸水速度のオンライン計測を行うことは 不可能である.そこで, 本研究では熱流制御法 (HFC 法：北野・江口，1986）を採用して, キュウリ植物の 茎の基部における茎内水流量のオンライン計測を行 い, 個体あたりの根の吸水速度とした（Fig. 1).

Fig. 2 に, HFC システムの模式図を示す. センサ部 分は, 密巻きマンガニン線のメインヒータと上下 2 個 のサブヒータおよびメインヒータ周囲の温度差を検出 する 4 組の $\mathrm{T}$-熱電対（直径 $0.1 \mathrm{~mm}$ ）で構成されてい る.キュウリ植物の茎の基部にメインヒータを装着し, その表面にプラスチックテープを巻いた.さらに 2 個 のサブヒータをメインヒータの上下それぞれ $1 \mathrm{~cm}$ 離 れた部位に装着した.メインヒータ上下の茎温差 $\left(T_{\mathrm{u}}-T_{\mathrm{d}}\right)$ およびメインヒータと上下それぞれのサブ ヒータとの間の茥温差 $\left(T_{\mathrm{u}}-T_{\mathrm{u}}{ }^{\prime}\right.$ および $\left.T_{\mathrm{d}}-T_{\mathrm{d}}{ }^{\prime}\right)$ を茎 に挿入した熱電対で検出した。 また，メインヒータ表 面とその外側のプラスチックテープ表面との温度差 $\left(T_{\mathrm{s}}-T_{\mathrm{s}}{ }^{\prime}\right)$ も熱電対で検出した. 気温変動および光照射 による外乱を防ぐために，センサ部分を発泡スチロー
ルの断熱ケースで被覆した.

メインヒータからの加熱量 $(Q)$ は茎内水流に伴う熱 フラックス $\left(q_{\mathrm{f}}\right)$, メインヒータ表面からプラスチック テープへの熱伝導による熱フラックス $\left(q_{\mathrm{s}}\right)$ およびメイ ンヒータからそれぞれ上下方向への茎内の熱伝導によ る熱フラックス（ $q_{\mathrm{u}}$ および $q_{\mathrm{d}}$ ) に分配される（すなわ ち, $\left.Q=q_{\mathrm{f}}+q_{\mathrm{s}}+q_{\mathrm{u}}+q_{\mathrm{d}}\right)$. そこで, 熱伝導による熱フ ラックス $q_{\mathrm{s}}, q_{\mathrm{u}}$ および $q_{\mathrm{d}}$ を引き起こす温度差 $T_{\mathrm{s}}-T_{\mathrm{s}}{ }^{\prime}$, $T_{\mathrm{u}}-T_{\mathrm{u}}{ }^{\prime}$ および $T_{\mathrm{d}}-T_{\mathrm{d}}{ }^{\prime}$ を, メインヒータおよび上下 サブヒータの電圧の操作により, それぞれ一定の設定 值 $S V_{\mathrm{s}}(>0), S V_{\mathrm{u}}(>0)$ および $S V_{\mathrm{d}}(>0)$ に制御し た.このことによって, $q_{\mathrm{f}}$ を除く熱フラックスの和 $\left(q_{\mathrm{s}}+q_{\mathrm{u}}+q_{\mathrm{d}}\right)$ がつねに一定に保たれ, メインヒータの $Q$ の操作量が $q_{\mathrm{f}}$ の変動に対応し, 基部の茎内水流量す なわち根の吸水速度 $(F)$ が次式で与えられる.

$$
\begin{aligned}
F & =\frac{Q-\left(q_{\mathrm{s}}+q_{\mathrm{u}}+q_{\mathrm{d}}\right)}{C_{\mathrm{w}}\left(T_{\mathrm{u}}-T_{\mathrm{d}}\right)}=\frac{Q-Q_{0}}{C_{\mathrm{w}}\left(T_{\mathrm{u}}-T_{\mathrm{d}}\right)} \\
& =\frac{V^{2}-V_{0}^{2}}{R C_{\mathrm{w}}\left(T_{\mathrm{u}}-T_{\mathrm{d}}\right)}
\end{aligned}
$$

ここで, $C_{\mathrm{w}}$ は水の比熱, $Q$ はメインヒー夕の電気抵抗 $R$ および電圧 $V$ により $Q=V^{2} / R$ で与えられる. $Q_{0}$ および $V_{0}$ は, $F=0$ すなわち $q_{\mathrm{f}}=0$ のときのメイン ヒータの加熱量と電圧で $Q_{0}=V_{0}^{2} / R=q_{\mathrm{u}}+q_{\mathrm{d}}+q_{\mathrm{s}}($ 一 定）である. $V$ および $T_{\mathrm{u}}-T_{\mathrm{d}}$ はオンラインでコン

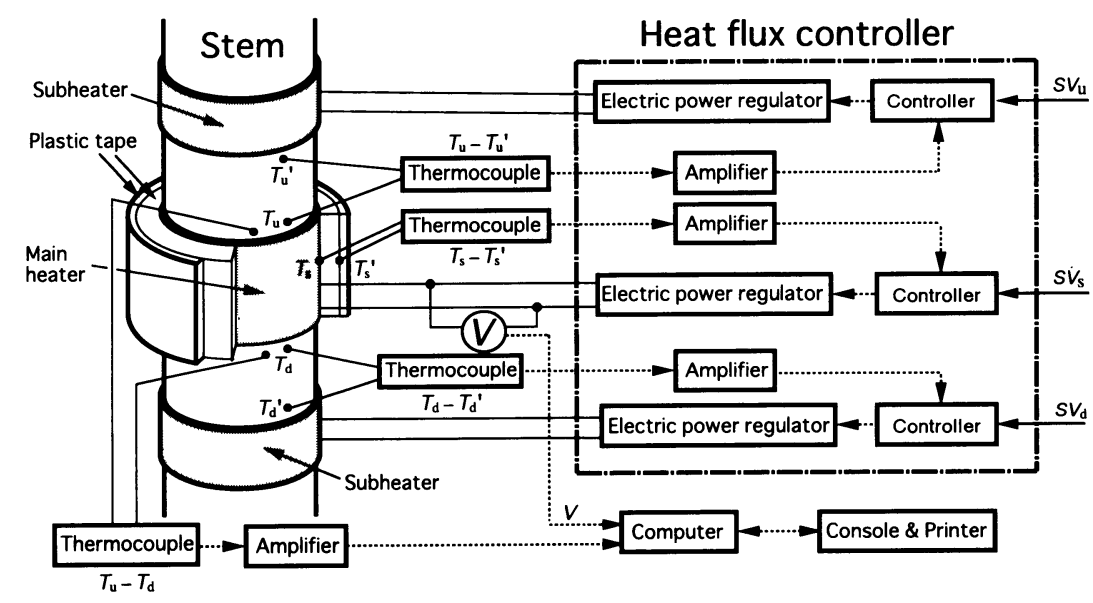

Fig. 2 Schematic diagram of the heat flux control (HFC) system for on-line measurement of water uptake rate in roots. $T_{\mathrm{s}}$, surface temperature of main heater; $T_{\mathrm{s}}{ }^{\prime}$, surface temperature of the plastic tape mounted on the main heater; $T_{\mathrm{u}}$ and $T_{\mathrm{d}}$, stem temperatures at the respective upper and lower end of the part heated by the main heater; $T_{\mathrm{u}}{ }^{\prime}$ and $T_{\mathrm{d}}{ }^{\prime}$, stem temperatures at points apart from the respective measuring points of $T_{\mathrm{u}}$ and $T_{\mathrm{d}} ; S V_{\mathrm{s}}, S V_{\mathrm{u}}$ and $S V_{\mathrm{d}}$, set values for the respective controls of $T_{\mathrm{s}}-T_{\mathrm{s}}{ }^{\prime}, T_{\mathrm{u}}-T_{\mathrm{u}}{ }^{\prime}$ and $T_{\mathrm{d}}-T_{\mathrm{d}}{ }^{\prime} ; V$, direct current voltage applied to the main heater for controlling $T_{\mathrm{s}}-T_{\mathrm{s}}{ }^{\prime}$. 
ピュータに入力し, $V_{0}$ は測定終了後に茥を切断して求 めた.

本システムは, $\pm 5 \%$ の測定精度と約 $1 \mathrm{~min}$ の時定数 を有し, 根の吸水の動的変化に十分追従が可能である (Kitano and Eguchi, 1989)。 また, 吸水量に対応して ヒータの加熱量が操作されるので, 茎の加熱部位の温 度場に急激な変化は生じず, 茎温の上昇も $5^{\circ} \mathrm{C}$ 以下に 抑えられ, 吸水に対する加熱の影響は認められなかっ た.

\section{結果および考察}

\section{溶存 $\mathbf{O}_{2}$ 濃度の制御結果}

$25^{\circ} \mathrm{C}$ における飽和溶存 $\mathrm{O}_{2}$ 濃度は $0.25 \mathrm{mM}$ である が,ここでは最高值を $0.20 \mathrm{mM}$ とした. Fig. 3 に設定 値を $0.01 \mathrm{mM}$ (a), $0.10 \mathrm{mM}$ (b) および $0.20 \mathrm{mM}$ (c) と した場合の溶存 $\mathrm{O}_{2}$ 濃度の経時変化を示す. 溶存 $\mathrm{O}_{2}$ 濃 度の変動はいずれも $00.005 \mathrm{~mm}$ の範囲内で, 本システ ムにおいて十分な精度で溶存 $\mathrm{O}_{2}$ 濃度を制御すること が可能であった。根の呼吸によりポット内に蓄積した 溶存 $\mathrm{CO}_{2}$ は送液ポンプ作動時に培養液とともに排出 され, 溶存 $\mathrm{CO}_{2}$ 濃度は $0.5 \pm 0.1 \mathrm{mM}$ の範囲に維持され た.このときの $\mathrm{pH}$ は $5.0 \pm 0.6$ の範囲であった.

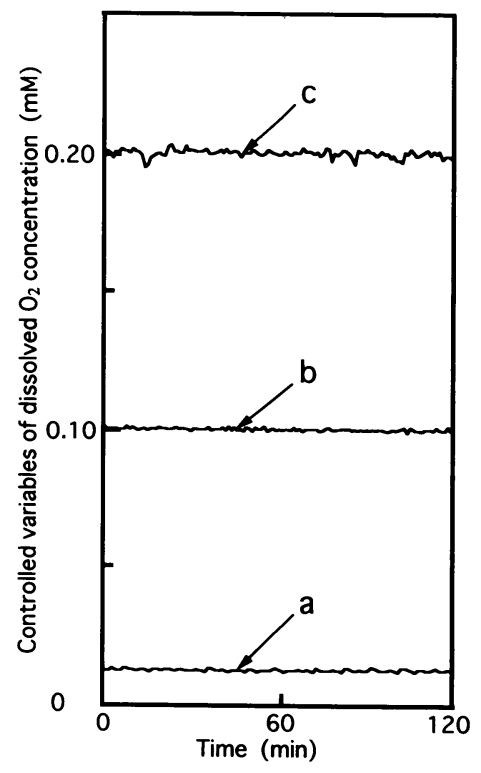

Fig. 3 Controlled variables of dissolved $\mathrm{O}_{2}$ concentrations at the respective set values of $0.01 \mathrm{~mm}$ (a), $0.10 \mathrm{~mm}$ (b) and $0.20 \mathrm{mM}$ (c) at a root temperature of $25^{\circ} \mathrm{C}$ in the control system of dissolved $\mathrm{O}_{2}$ concentration in hydroponics.
低溶存 $\mathrm{O}_{2}$ 濃度 $(0.01 \mathrm{~mm})$ 条件下においても, キュ ウリ植物に根の褐変, 葉の萎调およびクロロシス等は 認められなかった。

\section{根の吸水速度に対する溶存 $\mathbf{O}_{2}$ 漕度の作用}

Fig. 4 に, 溶存 $\mathrm{O}_{2}$ 濃度の設定値を $0.01 \mathrm{mM}(\mathrm{a}), 0.10$ $\mathrm{mM}$ (b) および $0.20 \mathrm{mM}$ (c) とした条件下における吸 水速度の経時変化を示す.いずれの溶存 $\mathrm{O}_{2}$ 濃度条件 下においても, 吸水速度は光条件に同調して変動した。 すなわち, 吸水速度は光照射によって急速に増加し, 消灯後に急速に隇少した.ここで $8: 00$ の光照射開始 3 $\mathrm{h}$ 前から吸水速度が徐々に増加する傾向がみられた が,このことは育苗時の光周期の前歴に馴らされた気 孔運動が維持されていると考えられる. 吸水速度は溶 存 $\mathrm{O}_{2}$ 濃度を $0.20 \mathrm{mM}$ とした条件において増加した。 すなわち, 暗黒下の 4:00における吸水速度は, 溶存 $\mathrm{O}_{2}$ 濃度が $0.01 \mathrm{mM}$ において $0.6 \mathrm{mg} \mathrm{s}^{-1}$ および $0.10 \mathrm{~mm}$ において $0.7 \mathrm{mg} \mathrm{s}^{-1}$ であったのに比べ, $0.20 \mathrm{~mm}$ にお いて $1.2 \mathrm{mg} \mathrm{s}^{-1}$ で大となった(5\%レベルで有意). 同様 に, 光照射下の $14: 00$ における吸水速度は, 溶存 $\mathrm{O}_{2}$ 濃 度が $0.01 \mathrm{mM}$ において $3.2 \mathrm{mg} \mathrm{s}^{-1}$ および $0.10 \mathrm{mM}$ にお

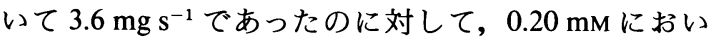
て $4.2 \mathrm{mg} \mathrm{s}^{-1}$ で大となった(5\%レベルで有意).このよ うに, 暗黒下および光照射下において溶存 $\mathrm{O}_{2}$ 濃度を

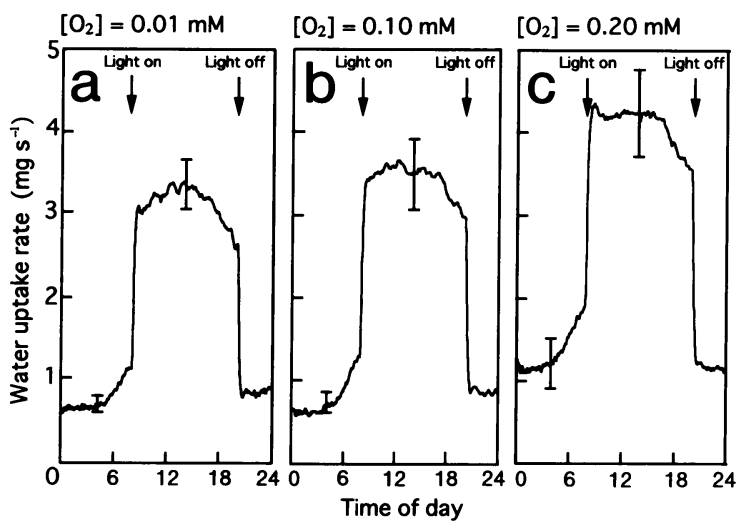

Fig. 4 Time course patterns of water uptake rate in roots at the respective dissolved $\mathrm{O}_{2}$ concentrations of $0.01 \mathrm{~mm}$ (a), $0.10 \mathrm{~mm}$ (b) and $0.20 \mathrm{~mm}$ (c) at a root temperature of $25^{\circ} \mathrm{C}$, an air temperature of $25^{\circ} \mathrm{C}$, a relative humidity of $70 \%$ and a PPFD of $300 \mu \mathrm{mol} \mathrm{m}^{-2} \mathrm{~s}^{-1}$ in a photoperiod of $12 \mathrm{~h}(8: 00-20: 00)$.

The means of measured values in 3 plants are plotted with the respective $95 \%$ confidence limits at $4: 00$ and $14: 00$. 
$0.10 \mathrm{~mm}$ 以下とした条件で根の吸水速度の減少が認め られたことから, 低溶存 $\mathrm{O}_{2}$ 濃度では根の吸水が抑制 されることが明らかとなった。ここで, 溶存 $\mathrm{O}_{2}$ 濃度が 最も低い $0.01 \mathrm{mM}$ においても吸水速度は $0.6 \mathrm{mg} \mathrm{s}^{-1}$ (暗黒下) から $3.2 \mathrm{mg} \mathrm{s}^{-1}$ (光照射下) の範囲にあり, 根の吸水が完全に停止して0レベルとなることはな かった. Yoshida and Eguchi (1994) は, 低溶存 $\mathrm{O}_{2}$ 濃 度条件下において地上部環境の $\mathrm{O}_{2}$ が葉をとおして根 に供給され, 根の呼吸が維持されるとともに吸水が改 善されることを明らかにしている.本研究においても, 低溶存 $\mathrm{O}_{2}$ 濃度において地上部から葉をとおして輸送 された $\mathrm{O}_{2}$ により根の吸水がある程度維持されたと考 えられる。

Fig. 5 に, 各溶存 $\mathrm{O}_{2}$ 濃度条件下における, 光照射下 $(12 \mathrm{~h})$ の吸水量, 暗黒下 $(12 \mathrm{~h})$ の吸水量および 1 日 間の吸水量を示す. 光照射下の吸水量は, 溶存 $\mathrm{O}_{2}$ 濃度 が $0.01 \mathrm{~mm}$ において $130 \mathrm{~g}, 0.10 \mathrm{mM}$ において $150 \mathrm{~g} て ゙$

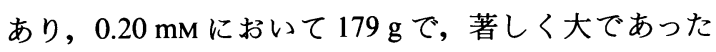
(1\%レベルで有意). 同様に, 暗黒下の吸水量は, 0.01

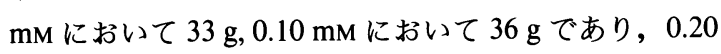
$\mathrm{mM}$ において $56 \mathrm{~g}$ で著しく大であった(1\%レベルで有

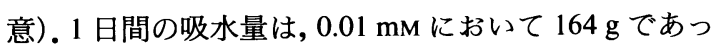

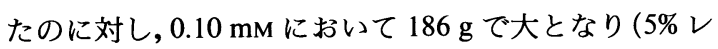
ベルで有意),さらに $0.20 \mathrm{~mm}$ においては $235 \mathrm{~g} て ゙$ 著し

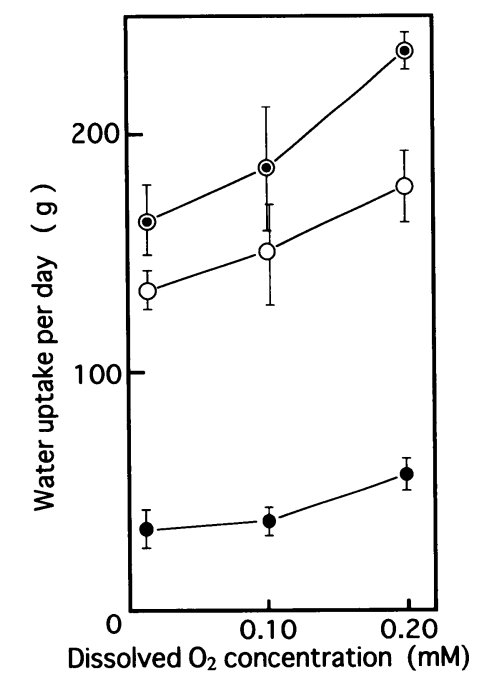

Fig. 5 Water uptakes in light $(\bigcirc)$, in darkness $(O)$ and in a whole day $(\mathrm{O})$ at dissolved $\mathrm{O}_{2}$ concentrations of $0.01,0.10$ and $0.20 \mathrm{~mm}$.

The means of measured values in 3 plants are plotted with the respective $95 \%$ confidence limits.
く大となった ( $1 \%$ レベルで有意).このように, 溶存 $\mathrm{O}_{2}$ 濃度の低下に対応して吸水量が減少することから, 低 溶存 $\mathrm{O}_{2}$ 濃度条件下で吸水が抑制されることが明確に 示された. Chun and Takakura (1994) は, レタスの 水耕において溶存 $\mathrm{O}_{2}$ 濃度が $0.07 \sim 0.26 \mathrm{mM}$ の範囲で, 溶存 $\mathrm{O}_{2}$ 濃度の低下に伴って根の呼吸速度が減少する ことを明らかにしている. 以上のことから, 本研究に おけるキュウリにおいても低溶存 $\mathrm{O}_{2}$ 濃度での吸水量 の減少に並行して根の呼吸も抑制されていることが推 測される.

根の吸水は, 蒸散で生じる圧ポテンシャル勾配およ びイオンの能動輸送で生じる浸透ポテンシャル勾配に よって引き起こされる(Nobel, 1991). 本研究では, 低 溶存 $\mathrm{O}_{2}$ 濃度条件下においても光照射に同調した周期 的な気孔運動が維持されており (Fig. 4), しかも地上 部環境の空気飽差が $6.9 \mathrm{~g} \mathrm{~m}^{-3}$ と大きいことから, 蒸散 による圧ポテンシャル勾配が吸水のおもな推進力 (driving force) になっていると考えられる. Everard and Drew (1987, 1989) はトウモロコシ (Zea mays L.) およびヒマワリ (Helianthus annuus L.) を用いて, 圧ポテンシャル勾配が一定の条件下で吸水が $\mathrm{O}_{2}$ 欠乏 により抑制されることを明らかにしている.このこと は, 低溶存 $\mathrm{O}_{2}$ 濃度条件下では根の通水抵抗が増大す ることによって吸水が抑制されることを示唆してい る. 根の通水抵抗は根の表面から中心柱の導管までの 経路における吸収抵抗および導管内における通導抵抗 から構成されるが, 長野・石田（1984）および長野ら (1993) は, 全根系の通水抵抗に占める吸収抵抗の割合 が $80 \%$ 以上であることを明らかにしている.したがっ て, 水が根の柔細胞組織を透過して導管に取り込まれ るまでに介在する膜の透過性が根の吸水を支配してい ると考えられる.このことから, 低溶存 $\mathrm{O}_{2}$ 濃度条件下 では, 根の呼吸が抑制されることにより, 根の細胞の 膜透過性が低下して根の吸収抵抗が増加した結果, 根 の吸水が抑制されることが推測される.さらに, Katou and Taura (1989) は, 圧ポテンシャル勾配で引き起こ される吸水においても，プロトンポンプによるイオン 輸送が根の中の水輸送に関連するという仮説を提唱し ている.このことから, 溶存 $\mathrm{O}_{2}$ 濃度の低下により根の 呼吸が抑制された条件下では, イオン輸送のメカニズ ムをとおしても，根の吸水が影響を受けることが考え られる.このように, 溶存 $\mathrm{O}_{2}$ 濃度が低い条件下では根 の吸水が抑制されることから, 溶存 $\mathrm{O}_{2}$ 濃度は呼吸が 関与する生理的プロセスをとおして根の吸水にも影響 
を与えることが示唆される．したがって，植物生産場 面においてもより活発な根の吸水を保つためには溶存 $\mathrm{O}_{2}$ 濃度をできるだけ高く維持することが必要である ことがわかった.

\section{文献}

Atwell, B. J., Thomson, C. J., Greenway, H., Ward, G., Waters, I. 1985. A study of the impaired growth of roots of Zea mays seedlings at low oxygen concentrations. Plant Cell Environ. 8, 179-188.

Chun, C., Takakura, T. 1994. Rate of root respiration of lettuce under various dissolved oxygen concentrations in hydroponics. Environ. Control in Biol. 32 : 125-135.

Everard, J. D., Drew, M. C. 1987. Mechanisms of inhibition of water movement in anaerobically treated roots of Zea mays $\mathrm{L}$. J. Exp. Bot. 38 : 1154-1165.

Everard, J. D., Drew, M. C. 1989. Mechanisms controlling changes in water movement through the roots of Helianthus annuus L. during continuous exposure to oxygen deficiency. J. Exp. Bot. 40 : 95-104.

Giménez-Abian, M. I., de la Torre, C., Lopez-Saez, J. F. 1987. Growth and cell proliferation in Allium roots at different oxygen tensions. Environ. Exp. Bot. 27 : 233-237.

位田藤久太郎 1977. 養液栽培の培地管理.「施設園芸の環境と栽 培」(位田藤久太郎編) 誠文堂新光社, 東京, p 311-338.

Katou, K., Taura, T. 1989. Mechanism of pressure-induced water flow across plant roots. Protoplasma 150 : 124-130.

北野雅治・江口弘美 1986. 熱流制御法による茎内水流量のオン ライン計測. 生物環境調節 24: 109-115.

Kitano, M., Eguchi, H. 1989. Quantitative analysis of transpiration stream dynamics in an intact cucumber stem by a heat flux control method. Plant Physiol. 89 : 643-647.

長野敏英・石田朋靖 1984. 植物の水分状態とその制御に関する 研究. (3) 大豆の根の通水抵抗. 農業気象 40:229-233.

長野敏英・石田朋靖・森田茂紀 1993. 植物の水分状態とその制 御に関する研究. (4) 種々の根の通水抵抗について. 生物環 境調節 $31:$ 147-153

Nobel, P. S. 1991. Solute. In "Physicochemical and Environmental Plant Physiology," Academic Press, San Diego, p 109189.

Yoshida, S., Eguchi, H. 1994. Environmental analysis of aerial $\mathrm{O}_{2}$ transport through leaves for root respiration in relation to water uptake in cucumber plants (Cucumis sativus L.) in $\mathrm{O}_{2}$-deficient nutrient solution. J. Exp. Bot. 45 : 187-192.

Wiedenroth, E.-M. 1993. Responses of roots to hypoxia : their structural and energy relations with the whole plant. Environ. Exp. Bot. 33 : 41-51. 